\title{
PECULIARITIES OF DECENTRALIZATION OF PUBLIC GOVERNANCE IN THE CONDITIONS OF DEMOCRATIC TRANSFORMATION IN UKRAINE
}

\author{
Natallia Gavkalova ${ }^{1}$, Alina Zilinska ${ }^{2}$, Vita Kurdiukova ${ }^{3}$ \\ ${ }^{1}$ Doctor of Science in Public Administration, Professor of the Department of Public Administration and \\ Regional Economy, Simon Kuznets Kharkiv National University of Economics, Kharkiv, Ukraine, e-mail: \\ ngavl@ukr.net, ORCID: https://orcid.org/0000-0003-1208-9607 \\ ${ }^{2}$ Ph.D., Lecturer of the Department of Public Administration and Regional Economy, Simon Kuznets Kharkiv \\ National University of Economics, Kharkiv, Ukraine, e-mail: alina_0707@ukr.net, ORCID \\ https://orcid.org/0000-0002-6591-0051 \\ ${ }^{3}$ Graduate student of the Department of Public Administration and Regional Economy, Simon Kuznets \\ Kharkiv National University of Economics, Kharkiv, Ukraine, e-mail: kyry4enkovitakvr@gmail.com, ORCID \\ https://orcid.org/0000-0002-5980-7699
}

Abstract. Theoretical aspects of decentralization as foundation of establishment of democratic model of governance are analyzed in the article. The aim of the article is a comprehensive scientific analysis of the nature of decentralization of power as a mechanism for limiting state power in the context of democratic transformation to provide practical recommendations for further decentralization reform in Ukraine. To this end, the following tasks are set: to highlight the features of the reform of decentralization of public power in a democratic transformation; to offer practical recommendations on the optimization of executive bodies and the expansion of local self-government bodies power in the process of carrying out the constitutional reform in Ukraine. The theoretical basis of the paper are the scientific works of foreign and domestic experts in the field of theory of state and law, constitutional law, administrative law. Such general scientific methods as: logical method, forecasting method, historical method and others are used in the research. The analysis of the category "decentralization of power" was also carried out using a logical method, which revealed the objective patterns of development of this phenomenon in legal science and state-building practice, as well as to determine the characteristics of decentralization of public power. The comparative legal method helped to find the ways to improve the current legislation on the decentralization of public power in the unitary state. In turn, using the method of legal modeling, conclusions are proposed and substantiated aimed at improving the current legislation on the decentralization of public power, as the basis for the formation of civil society. Importance of implementation of the reform of power decentralization for the development of Ukraine as a democratic constitutional state is proved. The legislative framework for the implementation of the reform of decentralization of power is analyzed. The author investigates the problems of decentralization in Ukraine, determines the advantages of decentralized management and possible risks. A conclusion demonstrates that implementation of processes of decentralization will facilitate democracy strengthening and increase its stability.

Keywords: decentralization of power, state, democracy, democratic governance, civic society, local self-government.

JEL Classification: H11, H73, R59

Formulas: 0; fig.: 0; tabl.: 0; bibl.: 32

Introduction. At the current stage of Ukraine`s development as a democratic state governed by the rule of law, an important role is played by the introduction of decentralization reform, which includes establishing democratic governance, transferring power to territorial bodies, ensuring broad participation of citizens in 
governance. The problem of decentralization is quite relevant today and is widely discussed by academia, experts and the public. The development of public relations, the formation of civil society necessitate a revision of the traditions of domestic statehood and the introduction of the practice of decentralization of power in Ukraine, based on the analysis of national features of the legal system and the world experience in this sphere. Decentralization of power is undoubtedly one of the most effective ways to update the system of public administration, which leads to a significant increase in its efficiency and becomes the basis for further development of democratic processes in the state..

Literature review. V. Averyanov, V. Bakumenko, O. Borislavska, M. Bratkovsky, I. Hrytsyak, V. Groysman, B. Danylyshyn, A. Lelechenko, V. Mamonova, O. Skrypniuk, I. Tsurkanova and others pay attention to the study of theoretical and practical issues of decentralization of power, development of local self-government. However, despite a number of scientific investigations, this issue remains quite relevant and needs further research. Also, the problem of the article should be considered more deeply from the standpoint of legal and methodological support, so the sources used in the article are mostly legal in nature. Among them are the legislation of Ukraine, bylaws, methodological developments and recommendations for decentralization in Ukraine. In particular, the Budget Code of Ukraine, the Law of Ukraine "On Local Self-Government in Ukraine", the Law of Ukraine "On Education". Voluntary association of territorial communities" [1;2].

Aims. The aim of the article is a comprehensive scientific analysis of the nature of decentralization of power as a mechanism for limiting state power in the context of democratic transformation to provide practical recommendations for further decentralization reform in Ukraine. To this end, the following tasks are set: to highlight the features of the reform of decentralization of public power in a democratic transformation; to offer practical recommendations on the optimization of executive bodies and the expansion of local self-government bodies power in the process of carrying out the constitutional reform in Ukraine.

Methods. The theoretical basis of the paper are the scientific works of foreign and domestic experts in the field of theory of state and law, constitutional law, administrative law. Such general scientific methods as: logical method, forecasting method, historical method and others are used in the research. The analysis of the category "decentralization of power" was also carried out using a logical method, which revealed the objective patterns of development of this phenomenon in legal science and state-building practice, as well as to determine the characteristics of decentralization of public power. The comparative legal method helped to find the ways to improve the current legislation on the decentralization of public power in the unitary state. In turn, using the method of legal modeling, conclusions are proposed and substantiated aimed at improving the current legislation on the decentralization of public power, as the basis for the formation of civil society. 
Results. Decentralization of public power is an integral part of legal and political reality of today, the key to effective democracy and the basis for the rule of law. At the same time, the harmonious development of this phenomenon in accordance with the needs and requirements of the time directly depends on a deep and comprehensive study of its genesis. The history of American and European legal thought contains two different models of decentralization of power that need to be understood in the context of modern state-building practice. In addition, decentralization requires a thorough analysis as one of the principles of democratic governance in the process of forming the constitutional state. Development of the idea of decentralization in Ukrainian political and legal thought and state-building practice cannot be overlooked either.

It is necessary to pay special attention to the views on the issues of decentralization of the well-known Ukrainian lawyer, the researcher of local selfgovernment Yu. Paneiko. He is a strong supporter of the state theory of local selfgovernment and shares the opinion that local authorities are essentially state bodies, as these bodies are called to life by law. From his point of view, "self-government is based on the requirements of the law with a decentralized state administration, performed by local authorities, which are not hierarchically subject to other bodies and are independent within the law and the general legal order" [3, p. 15].

Although the term "decentralization of power" was not used at that time, but the first systematic conclusions and scientific and practical recommendations of scientists of this historical period became the basis for further doctrinal studies of public power decentralization. In fact, territorial decentralization in its modern sense has its origins in this period and its essence is to create local governments that govern in individual territorial units independently, addressing community issues on the ground $[4, \mathrm{p}$. 197].

Based on the semantics of the term "decentralization" we can understand it as a specific process or set of processes that affect public relations.

According to A. Kovalenko, the essence of decentralization is reduced to political and legal elements of the relationship between community and state, which form a special legal regime and it gives local authorities independence and hierarchical independence from public administration and self-government [5].

Sharing the above opinions, we add that at the same time decentralization is an important legal mechanism for limiting public power. An effective system of decentralization of power is a prerequisite for the formation of the rule of law, as it prevents the central government from taking a dominant position in areas indistinctive to them. In addition, the decentralization of public power is the basis for the implementation of other levers of public power restriction, including human and civil rights and freedoms, the rule of law and the Constitution, mutual control as a manifestation of checks and balances and many others. 
At present Ukraine is in a state of active reform of public administration system on the basis of decentralization. At the same time, the process of limiting the powers of local executive bodies, increasing the powers of local governments should be based on systematic and balanced changes to regulations in this area.

Reform of executive bodies should be carried out under certain legal conditions: - establishment of a single administrative-territorial system of government;

- creation of a unified system of local governmental bodies at the regional and local levels;

- transformation (rather than preservation) of central public administration bodies at the public level;

- creation of a separate institute of state supervisors;

- coordination of decisions by territorial representations of central executive bodies with local self-governments, etc. [6].

Thus, the formation of decentralization of public administration in Ukraine should be carried out through gradual and logical reform of the executive branch, which should result in the transfer of powers from the executive to local governments.

The fourth stage (2014 - present) is a period of active implementation of public decentralization reforms. This period has the following characteristics:

1) implementation of the conceptual principles of reforming local self-government and territorial organization of power in Ukraine;

2) development of a mechanism for the creation, operation, financing and cooperation of territorial communities;

3) development of regional strategies and policy;

4) improvement of the administrative-territorial structure;

5) expansion of the field of administrative services;

6) further development and balancing of the current legislation on the implementation of reforms in the administrative, political, social, economic spheres, etc .;

7) formation of a priority task, which is the formation of civil society.

One of the first legislative acts on decentralization reforms in Ukraine at this stage is the Law of Ukraine "On Cooperation of Territorial Communities" dated on June 17, 2014 № 1508-18. It should also include the Law of Ukraine "On Optimization of the System of Central Executive Bodies" № 442 on July 10, 2014, which contains the approved scheme of delegation of powers between central executive bodies.

Instead, V. Kravchenko and S. Davydovych emphasized in their research that local self-government should be considered as the basis of the constitutional order, which is one of the most important principles of organization and functioning of power in society and a necessary attribute of any democratic system [7]. Although the institution of local self-government plays an important role in the process of public 
power decentralization. It is not advisable to consider it apart from the issue of territorial organization of power in Ukraine.

On this basis, it is appropriate to draw an intermediate conclusion that the development of local government in the context of decentralization reforms should be studied in inseparable connection with the feasibility of introducing territorial organization of government, which in essence is a reasonable territorial basis for local governments and executive authorities able to ensure the availability and quality of administrative and social services provided by these bodies. The conceptual foundations of local self-government and territorial organization of power in Ukraine were approved by the order of the Cabinet of Ministers of Ukraine № 333-r on April 1,2014 [8].

The need to adopt conceptual frameworks was due to a number of negative factors, namely:

- the development of local self-government stopped at the level of territorial communities after the adoption of the Constitution of Ukraine and relevant regulations on local self-government, as the material and financial base of territorial communities could not adequately ensure all the powers of local self-governments;

- the need of a constantly evolving society is growing, and accordingly the existing system of local self-government needs to be improved;

- the failure of local self-governments to provide functional support for a favorable living environment necessary for comprehensive human development, selfrealization, protection of human rights, provision of quality and accessible administrative and social services through sustainable community development;

- the system of territorial organization of power does not correspond to the development of society and requires an increased efficiency of social development management in the relevant territory;

- the presence of shortcomings in the administrative-territorial structure, which led to the defects in the territorial organization of power. Such defects of the territorial organization of power are: the lack of an integral territory of the administrative-territorial unit of the basic level; stay of the territorial community of the village, settlement, city as a part of other territorial community or on the territory of another administrative-territorial unit, territorial community of the district in the city;

- conflict of relations between public authorities on the ground, namely between local governments and local executive bodies, etc.

The analysis of special literature provides us with the grounds for concluding that the reform of local self-government on the basis of decentralization in Ukraine requires the creation of its integrated system, improving the legal support of local self-government. Peculiarities of local self-government reforming and territorial organization of power on the basis of decentralization are the development of a comprehensive approach to substantive legislation; phasing and coherence of 
legislative activity, which requires, first of all, the formation of strategic foundations for the development of local self-governments in terms of reforming the territorial organization of power. The above-mentioned facts indicate that in the process of local self-government reforming and territorial organization of power are two separate types of decentralization synergistically intertwined: managerial and administrative ones.

At the same time, only their comprehensive consideration will provide us with the grounds for effective and proper implementation of reforms in the field of local self-government and territorial organization of power, eliminate a number of risks and problems in the decentralization of public power in Ukraine.

At the same time, the practical process of implementing decentralization reforms in this direction has revealed problematic issues that need to be regulated. For example, the adopted Law of Ukraine "On Amendments to Certain Legislative Acts of Ukraine Concerning Voluntary Accession of Territorial Communities" introduced the procedure for voluntary accession to an already established association of territorial communities; clarified the requirements for the recognition of the united territorial community as capable. Due to the adoption of the Law of Ukraine "On Amendments to Certain Legislative Acts of Ukraine on Peculiarities of Voluntary Association of Territorial Communities Located in Adjacent Areas" a mechanism was introduced to create united territorial communities, which may include territorial communities of neighboring administrative districts and provided an opportunity to create a united territorial community, the center of which is a city of regional importance, as well as determined the procedure for calling the first local elections in such communities. The Law of Ukraine "On Amendments to Certain Laws of Ukraine on the Status of Elders of Villages, Settlements" improved the functioning of the institute of elders in united territorial communities, as well as clarified the legal status of elders, defined its powers and forms of accountability and responsibility to the community united territorial community.

Therefore, in order to improve the legal support of decentralization reform in the field of local self-governments, it is advisable to prepare the Law of Ukraine "On Local Self-Government in Ukraine" improving the legal support for the functioning of effective local self-governments and territorial organization of power on the basis of decentralization.

The peculiarity of reforming the territorial organization of power in Ukraine on the basis of decentralization is the need to increase the efficiency of local governments, which, in turn, will ensure proper resolution of local issues and create positive conditions for socio-economic development. Reforms in the field of territorial organization of power will strengthen the position of local selfgovernments at both the regional and district levels, as well as make changes in the functional load and organizational structure of local executive bodies. 
The above gives grounds to formulate the conclusion that the processes of local self-government reforming and territorial organization of power on the basis of decentralization in Ukraine should be systemic in nature and include the following stages:

- legal and state support for voluntary association of small territorial communities;

- consolidation of self-governing administrative-territorial units;

- compact territorial location of settlements;

- introduction of economic zoning [9];

- proper ensuring of the exercise by local governments of their own and delegated powers;

- prevention of duplication of powers, functions and tasks of local governments at different levels, as well as local executive bodies;

- establishment of mechanisms of state control over the legality of decisionmaking of local governments and the quality of public services;

- maximum involvement of the population in managerial decision-making, promoting the development of forms of democracy on the ground;

- redistribution of power in favor of local self-government, expanding their independence and increasing the responsibility;

- search for territorial and institutional boundaries of the organization of power;

- providing financial support to businesses of all forms of ownership (registered in a particular region) in order to implement investment, innovation, infrastructure and other projects of strategic importance to increase the competitiveness of a region;

- increase funding for education, health and social protection;

- reduction of the tax burden on the population of a region;

- expanding the functions of local tax payments;

- introduction of budget investment in social projects, etc.

Discussion. Thus, the development of the institution of local self-government in the context of decentralization is closely related to the optimization of territorial organization of power, which is a reasonable territorial basis for local governments and executive bodies, able to ensure accessibility and quality of administrative and social services.

A feature of the development of local self-government in the context of decentralization processes is the dualistic (state-community) concept, according to which local self-government is independent in matters of local economic affairs and is a part of public authority. Peculiarities of local self-government reforming and territorial organization of power on the basis of decentralization are the development of a comprehensive approach to substantive legislation; phasing and coherence of legislative activity, which requires, first of all, the formation of strategic foundations for the development of local self-governments in terms of reforming the territorial organization of power. At the same time, the practice of decentralization and the 
formation of capable territorial communities revealed a number of gaps and conflicts in the current legislation of Ukraine on the conceptual synergy enshrined in the Constitution of Ukraine principles of administrative and territorial organization and local self-government in Ukraine.

Therefore, in the draft laws on the development of the system of local selfgovernment, administrative-territorial structure, it is necessary to take into account the above peculiarities. Also, a preliminary international examination of the submitted bills will be expedient. This will allow the unifying of Ukrainian legislation with the European standards for the development of local self-government and the establishment of decentralization of power.

Conclusions. Law-making practice requires harmonization at the practical level of instruments of administrative, budgetary and economic decentralization. Currently, the issue of decentralization of powers of public authorities of both regional and local levels (local state administrations) is reduced to the scope of registration activities and regulatory functions for real estate transactions. Instead, decentralization in medical, educational, social, innovative and other spheres of public life requires deepening. In this way, the state will the appropriate conditions for strengthening the responsibility of local governments to address territorial development issues while giving them a level of opportunities, the implementation of which will localize any problems and issues of socio-economic development of the community.

\section{References:}

1. On voluntary association of territorial communities: Law of Ukraine of 05.02.2015 № 157-VIII. URL: https://zakon.rada.gov.ua/laws/show/157-19.

2. On local self-government in Ukraine: Law of Ukraine of 21.05.1997 № 280/97-VR. URL: http://zakon2.rada.gov.ua/laws/show/280/97-\%D0\%B2\%D1\%80/page.

3. Minchenko R.M. (2018). Problems of decentralization of state power and their interaction with local government in Ukraine, State and law, vol. 39, pp. 452-465.

4. Decentralization of public power: the experience of European countries and prospects of Ukraine. (2012). Borislavskaya O.M., Zaverukha I.B., Shkolyk A.M. and others; Center for Political and Legal Reforms. K .: Moskalenko O.M.,. 212 p.

5. Kovalenko A.V. (2012). Local governments in the system of state control over consumer protection., Theory and practice of public administration, vol. 4. pp. 374-379. URL: http://nbuv.gov.ua/UJRN/Tpdu_2012_4_54.

6. Zabeyvorota T.V. (2017). Modernization of public administration in the context of decentralization of power: author's ref. dis. Cand. Sciences of the state. management; [special] 25.00.01 "Theory and History of Public Administration". Kharkiv,. 20 p.

7. Kravchenko V.V. (2000). Constitutional law of Ukraine: textbook. manual. Ed .: Kopeychikov VV, Pukhtinsky MO Kyiv: Attica, 320 p.

8. On approval of the Concept of reforming local self-government and territorial organization of power in Ukraine: order of the Cabinet of Ministers of Ukraine № 333-r of 01.04.2014. Official site of the Verkhovna Rada of Ukraine. URL: http://zakon3.rada.gov.ua/laws/show/333-2014-\%D1\%80

9. Melnichenko O.A. (2016). Territorial organization of power in Ukraine: lecture notes. Kharkiv: FOP Leonov DS, 2016. $102 \mathrm{p}$.

10. Ostapenko O.G . (2016). Decentralization or federalization - the best way to reform public authorities in Ukraine, Legal scientific electronic journal, vol. 4, pp. 26-29

11. Podkovenko T.O., Figun N.I. (2017). The essence of law and the state in the work of S. Dnistryansky. Scientific Bulletin of Kherson State University. Ser ..: Legal Sciences. vol. 1 (1), pp. 42-46.

12. Alper Ozmen (2014). Notes to the concept of decentralization. European Scientific Journal. Edition.vol.10. pp. 415424.

13. Babych, O. M. (2011). Relationship between of centralization and decentralization in public administration, Chasopys Kyivskoho universytetu prav, vol. 12, pp. 109-113.

14. Dumke C. (2015). Daseinsvosorge, Wetibewerb und kommunale selbstverwaltung im Bereich der liberalisierten Energiewirtschaft. KWI-Gutachten: Universitat Potsdam, 180 p. 
15. Hendrych D., Shulova S. (2010). Overejne sprave. Praha: Univerzita Karlova v Praze, p. 270.

16. Jerzy Korczak, Piotr Lisowski, Adam Ostapski (2013). Ustoj samovradu terytorialnego: materialy dydaktyczne. Wroclaw: Prawnicza i Ekonomiczna Biblioteka Cyfrowa. $440 \mathrm{~s}$.

17. Soycon Kim, Wade Smith, Mitchell Sommers and Meredith Varela (2015). Power to the people: A Comprehensive Analysis of Determination in the East African Community. P. 45.

18. Stanford Encyclopedia of Phylosophy. Anfreas Gellesdal: Stanford, 2016.: http://plato.stanford.edu/entries/federalised/.

19. Beley L. (2014). Decentralization makes ordinary citizens responsible for their small homeland, Ukrainian week, vol. $17-18$, pp. 38-39.

20. Bohiv J.S. (2016). Legal problems of decentralization of power in the context of the realization of people's sovereignty in Ukraine, Historical and legal journal, vol. 1, pp. 92-96.

21. Bordenyuk V.I. (2005). Decentralization of state power and local self-government: concept, essence and forms (types), Law of Ukraine. vol. 1, pp. 21-25.

22. Vasylenko L., Dobrovinsky M. (2017). Decentralization and reform of local self-government, Entrepreneurship, economy and law. vol. 3, pp. 123-126.

23. Vlasyuk O.S. (2015). By way of decentralization: challenges, risks and priorities of regional development reform in Ukraine, Regional economy. vol. 1, pp. 5-18

24. Nataliia Gavkalova, Alina Zilinska, Volodymyr Polatay, Viktoriia Liashevska (2020). Organizational support for the development of united territorial communities. Public Policy and Administration. Vol 19, No 4, pp. $155-168$ DOI: https://doi.org/10.13165/VPA-20-19-4-11

25. Nataliia Gavkalova, Yuliia Lola, Svitlana Prokopovych, Alina Zilinska (2020). Socio-political development of countries in information society. Countries of the EU E3S Web Conf. Volume 166, 13015 DOI: https://doi.org/10.1051/e3sconf/202016613015

26. Zilinska A.S. (2019). Budget decentralization of the European Union and prospects for Ukraine. Black Sea Research Institute of Economics and Innovation. Odessa: Electronic scientific-practical magazine Market Infrastructure. vol. 36, pp. 547-552.

27.Zilinska A.S .(2019). Conceptual model of using organizational support for managing the economic potential of territorial communities. Public administration studies. vol. 10.http://studio.ipk.edu.ua/wpcontent/uploads/2021/03/Stattia_Zilins-ka-A.S._Derzhavno-upravlins-ki-studiii.pdf

28. Zilinska A.S . (2020). Factors influencing the effectiveness of the united territorial communities of Kharkiv region. $X$ International scientific and practical conference «Dynamics of the development of world science», June 10-12, 2020, Vancouver, Canada, pp. 405-410.

29. Nataliia Gavkalova, Alina Zilinska (2020). Practice and prospects of local economic development. International Scientific Conference on Service sector INSCOSES (15;2020; Ohrid) XV International Scientific Conference on Service sector INSCOSES 2020, Ohrid 11-12 September 2020. Ohrid : Faculty of tourism and hospitality, pp. 69-75.

30. Kolupaieva I. V. Gavkalova N. L. (2018). Decentralization of public administration in the process of building a democratic society Public Policy and Administration, Research Journal. vol. 17(2), pp. 216-225, DOI: https://doi.org/10.13165/VPA-18-17-2-05

31. Gavkalova N. L. Babenko K., Zolenko A. (2019). Formation of Information-Analitical System for Monitoring of the Economic Development of Territories,

International Journal of New Economics and Social Sciences, vol. $1 \quad$ (9). Warszawa ,pp. $197 \quad-\quad 206, \quad$ DOI 10.5604/01.3001.0013.3043

32. Smalskys, V., Babenko, K., Zolenko, Gavkalova N. L. (2020). Efficiency of the stakeholder interaction in the context of ensuring sustainable territorial development, Problems and Perspectives in Management, vol. 8(2), pp. 340349. DOI.org/10.21511/ppm.18(2).2020.28 